Article

\title{
Leveraging Fuel Subsidy Reform for Transition in Yemen
}

\section{Clemens Breisinger ${ }^{1, *}$, Wilfried Engelke ${ }^{2}$ and Olivier Ecker ${ }^{1}$}

1 International Food Policy Research Institute, Development Strategy and Governance Division, 2033 K St, NW Washington, DC 20006-1002, USA; E-Mail: O.Ecker@cgiar.org

2 The World Bank, 1818 H Street, NW Washington, DC 20433, USA;

E-Mail: Wengelke@worldbank.org

* Author to whom correspondence should be addressed; E-Mail: c.breisinger@cgiar.org; Tel.: +1-202-862-4638; Fax: +1-202-467-4439.

Received: 28 September 2012; in revised form: 17 October 2012 / Accepted: 17 October 2012 / Published: 30 October 2012

\begin{abstract}
Yemen is currently undergoing a major political transition, yet many economic challenges - including fuel subsidy reform - remain highly relevant. To inform the transition process with respect to a potential subsidy reform, we use a dynamic computable general equilibrium and microsimulation model for Yemen; we show that overall growth effects of subsidy reduction are positive in general, but poverty can increase or decrease depending on reform design. A promising strategy for a successful reform combines fuel subsidy reduction with direct income transfers to the poorest one-third of households during reform, and productivity-enhancing investment in infrastructure, plus fiscal consolidation. Public investments should be used for integrating economic spaces and restructuring of agricultural, industrial and service value chains in order to create a framework that encourages private-sector-led and job-creating growth.
\end{abstract}

Keywords: fuel subsidy reform; development; poverty; Middle East; Northern Africa; Yemen 


\section{Introduction}

Even before the "Arab Awakening" that sparked the uprising in Yemen and initiated the political transition, the country faced huge socio-economic challenges. In 2006, 35 percent of all Yemenis lived below the national poverty line [1], and estimates suggest that poverty and food insecurity increased substantially as a result of the global food crisis in 2008. Breisinger et al. [2] estimate that poverty increased to 43 percent in 2009, and Ecker et al. [3] and WFP [4] consistently estimate that 32 percent of the population was food insecure in 2009. Growth did not trickle down well to the poor, mainly because the economy is dominated by the capital-intensive hydrocarbon sector (that is, oil and gas exploration) and non-tradable services. Labor-intensive sectors such as agriculture and manufacturing make up a relatively small share of the economy. Even though about 70 percent of the population lives in rural areas, only about 30 percent of the population earns their main livelihood from farming with little alternative opportunities for non-farm employment [3,5].

While poverty and food insecurity have likely further increased during 2011, many of the structural and economic weaknesses and challenges remain. One of the major challenges has been the combination of declining oil revenues and rising fiscal costs to sustain Yemen's subsidy scheme in combination with a large budget deficit in 2009-estimated at about 10 percent of the GDP [6]. In fact, Yemen is among the high subsidizers in the Middle East and Northern Africa (MENA) region, and there are only a few other countries in the world with lower fuel prices than Yemen, such as Libya, Saudi Arabia, Bahrain, Qatar, and Kuwait, which all have significantly higher GDP and larger oil or gas reserves per capita [7]. In Yemen, as in other countries such as Azerbaijan, Bolivia, Ecuador, Egypt, Indonesia and Jordan, fuel subsidies account for more than three percent of GDP and are comparable in size to public spending on health and education combined [8-10]. Given that it is usually the better-off households that disproportionally benefit most from fuel subsidies, these subsidies are not only a blunt tool against poverty, but also increase inequality [9,11]. Additional detriments include an often inefficient fuel-processing sector and, given the premiums involved in the shadow market, smuggling and fuel adulteration.

An increasing number of governments therefore question the usefulness of their energy subsidy schemes, and several governments have launched substantial reforms lately, including Chile, Ghana, India, Iran and Syria. However, there is often uncertainty about the economic and social impact of potential reforms $[12,13]$. Many studies find that fuel subsidy reforms raise overall economic growth, mostly explained by economic efficiency gains over time [14-16]. Hope and Singh [17] studied the impacts of fuel subsidy reform in six countries (Columbia, Ghana, Indonesia, Malaysia, Turkey and Zimbabwe) and showed that in three of the countries studied (Columbia, Indonesia and Ghana) in the years during fuel subsidy reform, the GDP grew faster than before, and growth in the other three countries quickly accelerated in the years after the implementation of the reform [14-18]. Household welfare effects of fuel subsidy reform have been less widely studied; Coady et al. [9] found in their six-country study that real incomes of the poorest household groups declined between 1.8 percent in Mali and up to 9.1 percent in Ghana. Consistently, Hope and Singh [17] found decreases in real household incomes of 
1-3 percent due to subsidy reform in all of the six countries studied. These findings are further confirmed by the experience of the 2007-08 global food and fuel crisis, where rising prices for fuel products and food led to an increase in poverty [19]. These studies further show that the magnitude of poverty effects significantly differs between countries.

Past experience with subsidy reform suggests that protecting the poor from the negative impact of reform is most important for success. The immediate loss in real household incomes, especially among the poor, may explain why fuel subsidy reform is often accompanied by social tensions or even riots. Nonetheless, social unrest may be mitigated, if targeted compensation is provided and the reform process is accompanied by broad publicity campaigns that raise awareness of the social inequality created by subsidies and their inefficiency in fostering sustainable growth [20]. Several countries have successfully applied direct income transfers to protect the most vulnerable households from the negative impact. For example, Chile provided several rounds of cash transfers to the poorest 1.4 million households, China compensated the poor with monthly payments to offset rising fuel costs and Indonesia issued quarterly payments of US\$30 over one year for 15.5 million poor households (or 28 percent of the population). Ghana used a more indirect approach and abolished fees for all public primary and secondary schools and established a program to improve public transportation [20].

In this paper, we analyze the direct and indirect effects of reforming Yemen's fuel subsidy policy on growth and poverty. In addition to and based on lessons from other countries, we hypothesize that fuel subsidy reform can have significant growth effects but may slow poverty reduction substantially, if no additional measures are taken. To test this hypothesis, we use a dynamic computable general equilibrium (DCGE) model combined with a microsimulation model to estimate growth and poverty effects under two alternative reform options relative to a baseline scenario. The first scenario represents an accelerated reform path where all subsidies are lifted within one year, and the second scenario depicts a more gradual reform scenario that phases out subsidies over a period of three years. Under both scenarios, we simulate three alternatives for spending the savings from reform. In the first set of simulations, the total amount is used for budget deficit reduction. In the second set, parts of the savings are used for direct income transfers to the poorest 30 percent of households and, in the third set, for public investment in infrastructure in addition.

The rest of the paper is organized as follows: Section 2 describes the role of fuel subsidies in the Yemeni economy and argues that, independent of the outcome of the current uprisings, reforming the subsidy scheme remains a political challenge but is necessary for sustainable economic development. Section 3 presents the DCGE model and the reform scenarios of the simulation. Section 4 discusses the simulation results, and Section 5 concludes with policy implications.

\section{The Role of Fuel Subsidies and Political Challenge of Reform}

\subsection{The Role of Fuel Subsidies in Yemen's Economy}

Yemen's fuel subsidy scheme has been the largest single expenditure item in the national government budget since 2007. Fuel subsidies accounted for more than 20 percent of the government budget in 2007 
and 2009 and even more than 30 percent in 2008, exceeding the total spending on education, health and social transfers combined in 2007 and 2008 (Table 1) [21]. The share of the subsidies within the category of "economic affairs" has increased dramatically, up from about 45 percent of total economic affairs expenditures in 1999 to more than 90 percent in 2008. This expansion of cost for the fuel subsidy comes at the expense of other sectors, especially social sectors and infrastructure. The fiscal resources for social protection, for example, remained fairly low and accounted for only 0.2 percent of the total government spending in 2007 and 2008. Furthermore, less than one percent of the government's economic affairs budget was allocated to investments in transportation and telecommunication infrastructure in 2007-09. Nonetheless, there is broad consensus that the current under-investment in infrastructure and the resulting high transaction costs are main obstacles for job-creating growth, economic diversification and rural commercialization. Investments in the road network, particularly in rural areas, are expected to also have important spillover effects on people's living conditions through improved access to markets, health facilities, schools and other public services [22]. Thus, not only are fuel subsidies contributing to Yemen's large budget deficit, they also divert critical resources away from health, education and infrastructure sectors and thereby hamper long-term development prospects.

Table 1. Government budget spending by sector (percent of total government expenditure), 2007-09.

\begin{tabular}{lccc}
\hline \multicolumn{1}{c}{ Sector } & $\mathbf{2 0 0 7}$ & $\mathbf{2 0 0 8}$ & $\mathbf{2 0 0 9}$ \\
\hline Economic Affairs & 27.3 & 37.1 & 27.5 \\
of which: & & & \\
$\quad$ Industry \& Trade & 0.1 & 0.1 & 0.2 \\
$\quad$ Transportation \& Communication & 0.2 & 0.1 & 0.2 \\
$\quad$ Agriculture \& Fishing & 1.0 & 0.9 & 0.8 \\
$\quad$ Fuel Subsidies & 23.2 & 34.1 & 22.2 \\
$\quad$ Other & 2.8 & 1.9 & 4.0 \\
Health & 3.4 & 3.2 & 3.5 \\
Education & 14.5 & 13.1 & 16.3 \\
Social Protection & 0.2 & 0.2 & 2.7 \\
General Public Services & 24.0 & 20.3 & 18.2 \\
Defense & 15.7 & 13.3 & 16.4 \\
Other & 14.8 & 12.7 & 15.4 \\
\hline Total & 100.0 & 100.0 & 100.0 \\
\hline & Source: Ministry of Finance [23]. & & \\
\hline
\end{tabular}

The largest share of fuel subsidies goes to diesel, which made up 69 percent of the total subsidy spending in 2009; 14 percent was spent for subsidizing gasoline consumption, 11 percent for liquefied petroleum gas (LPG) consumption, and the rest for kerosene and jet fuel consumption [24]. Diesel has also been the most consumed petroleum product, with 3.96 billion liters in 2009, followed by gasoline (2.04 billion), jet fuel (1.34 billion), and kerosene (0.12 billion) [25]. Depending on the shares of 
petroleum products in production and consumption, the benefits from the subsidies and the losses occurring when phasing-out would differ between sectors and households. Most of the fuel is used for transportation and as intermediate inputs in industry and agriculture (Table 2). Forty percent of the total fuel is used by the transport sector, and transportation, in turn, is an important input for production in other sectors. Industry and services are the most transportation-intensive sectors with transportation making up 14 and 8 percent of their input costs, respectively. Directly the industry sector consumes 30 percent of all petroleum products and agriculture about 12 percent, mainly for irrigation. Despite subsidies, fuel is the single largest expenditure item for agricultural production [26]. Households' private consumption adds up to 10 percent of total fuel consumption.

Table 2. Fuel Use in Yemen.

\begin{tabular}{lccc}
\hline Economic sector & $\begin{array}{c}\text { Share in total fuel } \\
\text { consumption } \\
\text { (percent) }\end{array}$ & $\begin{array}{c}\text { Fuel intensity in } \\
\text { production/consumption } \\
\text { (percent) }\end{array}$ & $\begin{array}{c}\text { Import } \\
\text { intensity by } \\
\text { sector (percent) }\end{array}$ \\
\hline Agriculture & 12.4 & 19.6 & 49.8 \\
Petroleum products & 0.5 & 7.0 & 184.6 \\
Industry & 29.9 & 11.6 & 34.7 \\
Transport & 40.0 & 30.8 & - \\
Other services & 7.1 & 2.3 & - \\
Households & 10.1 & 1.2 & - \\
$\quad$ Urban & 37.1 & 1.1 & - \\
Rural & 62.9 & 1.2 & - \\
\hline
\end{tabular}

Source: Based on HBS [27] and SAM [19]; Note: Fuel intensity describes the share of fuel used in intermediate demand in the case of production activities and the share of fuel used in final consumption in the case of households. Import intensity describes the share of imported goods to its total domestic consumption.

In general, reducing fuel subsidies would affect household welfare directly through higher costs for fuel consumption and indirectly through higher costs for fuel-based goods and services and lower household incomes from fuel-consuming activities such as irrigated agriculture or transportation services. As in other countries, the direct expenditure for fuel consumption in Yemen is modest at 1805 Yemeni Rials (YER) per capita and year, or about 1.2 percent of household total expenditure, on average (Table 3). The per capita amount is higher for urban households (2659 YER) than rural households (1363 YER) in absolute terms. However, rural households spend a slightly higher share of their income on fuel consumption than urban households (1.2 percent compared with 1.1 percent). Yet the indirect consumption of fuel matters more for household real incomes. For example, household expenditure on transportation (of which 31 percent goes to fuel on average) is about eight times higher than their fuel consumption expenditure (Table 3). Transportation accounts for 8.7 percent of household expenditure nationwide, with a much higher share among urban households than rural households. 
Table 3. Share of fuel consumption and transportation in household expenditure.

\begin{tabular}{lccc}
\hline \multicolumn{1}{c}{ Household Expenditure } & Total & Urban & Rural \\
\hline Fuel & & & \\
\hline Per capita expenditure (YER/year) & 1805 & 2659 & 1363 \\
Share in total expenditure & 1.2 & 1.1 & 1.2 \\
\hline Transportation & & & \\
\hline Per capita expenditure (YER/year) & 13,281 & 46,130 & 6677 \\
Share in total expenditure & 8.5 & 12.9 & 5.8 \\
\hline Fuel plus transportation & & & \\
\hline Per capita expenditure (YER/year) & 15,086 & 48,790 & 8040 \\
Share in total expenditure & 9.7 & 14.0 & 7.0 \\
\hline
\end{tabular}

Source: Based on HBS [27] and SAM [28].

\subsection{The Political Challenge of Fuel Reform in Yemen}

Past experience shows that reducing the subsidies without providing direct income compensation and launching information campaigns and public dialogue can lead to major civil unrest. For example, as a response to a fuel price increase in 2005, violent clashes between protesters and security forces broke out across Yemen and left dozens of people dead. As a consequence, and due to mounting pressure, the Yemeni Government backed down from its reform attempt. A growing budget deficit led the government to another attempt of gradual phasing-out of fuel subsidies in 2010. The fuel price at the pump was increased in two steps by 10 percent each without major unrest. However, facing recent uprisings related to the "Arab Awakening", the government put the reform process on hold to avoid further opposition. It may well be that a new government will shy away from the fuel subsidy reform for political reasons in the short run. However, this is likely to come at increasingly high costs since Yemen's oil production is declining and consumption is increasing [22]. Maintaining fuel subsidies may then even require budget consolidation at the expense of already low welfare spending, and urgently needed investments in infrastructure, education and health, while cutbacks in these budget areas are another potential source of dissatisfaction among the people.

\section{Modeling Growth and Poverty Effects of Fuel Subsidy Reform}

\subsection{Yemen Dynamic Computable General Equilibrium Model}

As outlined in the previous section, fuel subsidies account for a large share of Yemen's government expenditure and play an important direct and indirect role for household incomes. Reducing the subsidies is likely to significantly reduce household welfare and alter the production costs of economic activities in the short run while freeing up substantial resources, which may be used for alternative spending. Estimating both the direct and indirect effects of fuel subsidy reform requires an economy-wide model that captures the linkages between the reduction of the subsidies, production, consumption, and household 
incomes. Given that many of the effects arise from changes in relative prices, social accounting matrix (SAM)-based computable general equilibrium models (CGE) models are more suitable than SAM-based multiplier models that have previously been used in comparable studies.

In this paper, we apply a recursive-dynamic computable general equilibrium (DCGE) model as described in Diao and Thurlow [29]. Recent applications of this model include, for example, Breisinger, Diao, and Thurlow [30] and Wiebelt et al. [31]. In the following model description we focus on the specific model features for Yemen, including a description of the social accounting matrix (SAM) as the main dataset, the choice of elasticities, macro- and labor-market closure rules and the description of exogenous shocks for the simulations.

We first update a 2007 SAM [32] to represent Yemen's economy in 2009 as the main database for the model. The main data sources for constructing the 2007 SAM include the latest supply-use table from the Central Statistics Organization of Yemen, balance of payments from the Bank of Yemen, government budget data from the Ministry of Finance, the 2008 Agricultural Yearbook from the Ministry of Agriculture and Irrigation, and the latest Household Budget Survey conducted in 2005-06. These data were complemented with data from the IMF and the World Bank. For updating the 2007 SAM to the economic conditions in 2009, we used national accounts data for 2009 provided by the Ministry of Planning and International Cooperation.

The Yemen DCGE model is very detailed at the production, commodity, factor, and household levels and includes 65 production activities, 65 commodities, 15 factors of production, and six household groups [33]. Factors of production include labor for three skill levels (unskilled, semiskilled and skilled) and employment in the public and private sectors. In addition to the SAM as the main data source to calibrate to a set of parameters in both production and demand functions, a DCGE model also requires several elasticities. The main elasticities include the substitution elasticity between primary inputs in the value-added production function, which determine the ease with which, for example, users of fuel can substitute it for other inputs; the elasticity between domestically produced and consumed goods and exported or imported goods; and the income elasticity in the demand functions. The income elasticity with regard to fuel, for example, measures how consumers react to higher prices. We estimated the elasticity of expenditure for commodities and services with respect to household income from a semi-log inverse function suggested by King and Byerlee [34] for rural and urban households separately, using data from HBS 2005-06. These elasticities range from, for example, 0.31 for cereal consumption to 2.2 for transport and 1.95 for fuel consumption, while most elasticities are lower for urban households than for rural [35]. Instead of elasticities that could not be estimated econometrically due to lack of data, we used international standard estimates provided by the International Food Policy Research Institute. For the substitution between intermediate inputs and value added in the production function, we assume constant elasticities of transformation that are 1.2 for the factor substitution elasticity, 4.0 for the elasticity of transformation, and 6.0 for the Armington elasticities of all goods and services [36].

In our simulations the dynamics of the DCGE model occur between 2010 and 2015 in each year. In the baseline scenario as well as in all subsidy reform scenarios, we assume that the nominal exchange rate is flexible. Exogenous variables in the model include government consumption, transfers to households, 
foreign inflows, population growth and, hence, growth of the workforce, which all grow exogenously according to their trends in recent years. Investments are savings driven, which means that an increase of either private or public savings increases the economy-wide investment rate. The government budget is flexible in the model, which means that the government can adjust to changes in revenues and spending by increasing or decreasing the budget deficit (or its savings). For example, if fuel subsidies are reduced, the government savings increase. This leads to an overall increase of savings in the economy, and thus to higher investment. It is important to note that real sector CGE models in general cannot capture the longterm benefits of low public debt or GDP levels and related lower interest rates for borrowing capital.

At the sector level, total factor productivity (TFP) increases exogenously to account for the differential growth patterns across sectors. Non-hydrocarbon capital is fully mobile across all sectors, and its intertemporal allocation follows the highest profitability by sector and period. Capital employed in the hydrocarbon sector is sector-specific and cannot move to other sectors. Population growth, land and productivity growth are all exogenously determined. Baseline growth in the model is driven by population growth (three percent), supply of labor (three percent), annual TFP growth changes of three percent in all non-agricultural sectors from 2010 to 2015 and an increase in government spending consistent with annual growth rates (three percent). Changes in growth rates in the different reform scenarios are relative to the baseline scenario are mainly due to endogenous processes such as the change of relative prices for factors and commodities from subsidy removal. Changes in public spending from subsidy reform are accounted for by exogenous changes in government transfers to households and sector level changes in TFP [37].

The six types of labor included in the DCGE model captures the distinct nature of the Yemeni labor market that is mainly characterized by public versus private employment and different skill levels. Accordingly, there are different wage rates for labor employed by the government and by the private sector. Workers are fully mobile within these employments and wage rates differ among skilled, semiskilled and unskilled labor. With this set-up, the model can capture some of the distributional effects of growth that has characterized the Yemeni economy over the past years such that growth has been oildriven and did not trickle down to the poor and rural areas [1]. In fact, the segmentation of the labor market, wherein only few highly skilled laborers in the oil sector and government employees benefited from oil production and related government revenues, has been deemed as a major obstacle to pro-poor growth and rural development [22].

\subsection{Microsimulation Model}

The DCGE model links to a micro-simulation model that allows for the endogenous estimation of growth effects on poverty reduction. The micro-simulation model uses data available for 13,136 households from HBS 2005-06. Each household's total consumption expenditure and expenditure shares on all consumed commodity groups are linked to one of the six representative household groups included in the DCGE model according to the household's residential area (rural or urban), employment in agriculture (farm or non-farm in rural areas) and food security status (food secure or food insecure). Relative changes in the consumption expenditure levels of the household groups, which are endogenously 
estimated in the DCGE model, are applied on the reported consumption expenditure levels of all survey households to obtain their new expenditure levels. Each household's new total consumption expenditure level is related to the official poverty line (available from HBS [27]) to determine its poverty status, based on which new poverty rates at the national level and for rural and urban areas and farm and non-farm households in rural areas are estimated. Household expenditure levels and poverty rates are computed for each year in each scenario simulation.

\subsection{Baseline and Fuel Subsidy Reform Scenarios}

The DCGE and micro-simulation models are applied to estimate growth rates and changes in poverty rates under a baseline scenario, which represents a continuation of the fuel subsidy policy without reform, and six fuel subsidy reform scenarios, which represent two reform options each with three alternatives of spending the reform savings. To determine the net effects of the reform options, growth and poverty rate estimates of the reform scenarios are compared with the baseline estimates, and simulation results are reported as changes from the baseline.

Reform Option 1 represents an accelerated reform path, wherein all fuel subsidies are lifted within one year; Reform Option 2 represents a more gradual reform path, where subsidies are phased out over a period of three years (Table 4). The base year of our simulation is 2009, and we assume exemplarily that the subsidy reform is implemented from year 2011 onwards. In the accelerated reform scenario, subsidies are eliminated from an estimated 391 billion YER in 2009 to zero through a one-time removal in 2011. This would, ceteris paribus, imply a reduction of the fiscal space by one-half, from 6.9 percent of GDP in 2009 to 3.5 percent in 2011, which yield a surplus of 215 billion YER [38]. In the gradual reform scenario, subsidies are phased out by equal amounts (130 billion YER) from 2011 through 2013. Ceteris paribus, the overall savings from the gradual reform are smaller than from the accelerated reform due to continued fiscal costs for subsidies in 2011 and 2012, so that the full fiscal space is also reached later.

Table 4. Fuel subsidy reform options.

\begin{tabular}{|c|c|c|c|c|c|c|c|}
\hline & \multirow[b]{2}{*}{2009} & \multicolumn{3}{|c|}{ Reform Option 1 (accelerated) } & \multicolumn{3}{|c|}{ Reform Option 2 (gradual) } \\
\hline & & 2011 & 2012 & 2013 & 2011 & 2012 & 2013 \\
\hline \multicolumn{8}{|l|}{ Fuel subsidies } \\
\hline Percentage change (percent) & & -100 & 0 & 0 & -33 & -50 & -100 \\
\hline Absolute change (billion YER) & & -391 & 0 & 0 & -130 & -130 & -130 \\
\hline Absolute change (million US\$) & & -1777 & 0 & 0 & -593 & -592 & -593 \\
\hline Remaining subsidies (billion YER) & 391 & 0 & 0 & 0 & 261 & 130 & 0 \\
\hline Remaining subsidies (million US\$) & 1777 & 0 & 0 & 0 & 1185 & 593 & 0 \\
\hline \multicolumn{8}{|l|}{ Fiscal space } \\
\hline Fiscal deficit (percent of GDP) & 6.9 & 3.5 & 3.5 & 3.5 & 5.8 & 4.6 & 3.5 \\
\hline Fiscal deficit (billion YER) & 352 & 176 & 0 & 0 & 293 & 235 & 176 \\
\hline Fiscal deficit (million US\$) & 1600 & 800 & 0 & 0 & 1333 & 1067 & 800 \\
\hline Surplus from reform/spending (billion YER) & & 215 & 0 & 0 & 72 & 72 & 72 \\
\hline
\end{tabular}


For both the accelerated and the gradual reform options, we analyzed the growth and poverty effects assuming that savings from the fuel subsidy reform are used (A) only for budget deficit reduction, (B) for budget deficit reduction and direct income transfers to the poorest one-third of households, and (C) for budget deficit reduction, direct income transfers targeted to the poorest one-third of all households, and productivity-enhancing investments in infrastructure. The simulations of the Spending Alternatives B and $\mathrm{C}$ require assumptions on the allocation of the reform savings and the size of the changes in productivity induced by the increases in public investments in the case of Alternative $C$ (Table 5). Yet the empirical evidence on the effects of infrastructure spending is ambiguous and often country-specific. A recent analysis by Dorosh and Thurlow [39] looking at road network investments in Ethiopia assumes TFP growth rates between 3.5 and 11 percent depending on the sector. We assume equal TFP growth rates for Yemen and consistently higher growth rates in construction sectors [40]. Accordingly, for Reform Option $1 \mathrm{C}$ and $2 \mathrm{C}$, we assume an overall investment-growth elasticity of 0.5 ; that is, a one percent increase in investment leads to 0.5 percent GDP growth.

Table 5. Reform scenarios (model implementation).

\begin{tabular}{|c|c|c|c|}
\hline & Government transfers & Subsidies & TFP \\
\hline \multicolumn{4}{|l|}{ Reform Option 1 (accelerated) } \\
\hline $\begin{array}{l}\text { 1A: } 100 \% \text { increase in government } \\
\text { savings }\end{array}$ & as baseline & $\begin{array}{l}100 \% \text { decrease of } \\
\text { subsidies in } 2011\end{array}$ & as baseline \\
\hline $\begin{array}{l}\text { 1B: Increase government savings by } \\
50 \% \text { and use remainder for direct } \\
\text { transfers to poorest one third of } \\
\text { households }\end{array}$ & $\begin{array}{l}\text { increase transfers in } 2011 \\
\text { between } 40 \% \text { and } 380 \% \\
\text { depending on initial size of } \\
\text { transfers and population shares }\end{array}$ & $\begin{array}{l}100 \% \text { decrease of } \\
\text { subsidies in } 2011\end{array}$ & as baseline \\
\hline $\begin{array}{l}1 \mathrm{C} \text { : Increase in government savings by } \\
50 \% \text {, compensate only the poorest of } \\
\text { the poor, and use remainder for } \\
\text { productivity-enhancing investments }\end{array}$ & $\begin{array}{l}\text { increase transfers in } 2011 \\
\text { between } 22 \% \text { and } 155 \% \\
\text { depending on initial size of } \\
\text { transfers and population shares }\end{array}$ & $\begin{array}{l}100 \% \text { decrease of } \\
\text { subsidies in } 2011\end{array}$ & $\begin{array}{l}22 \% \text { in construction, electricity, } \\
\text { water, trade transport in } 2011 ; \\
\text { from } 2013,1 \text { percent TFP } \\
\text { growth in all sectors }\end{array}$ \\
\hline \multicolumn{4}{|l|}{ Reform Option 2 (gradual) } \\
\hline $\begin{array}{l}2 \mathrm{~A}: 100 \% \text { increase in government } \\
\text { savings }\end{array}$ & as baseline & $\begin{array}{l}33 \%, 50 \%, 100 \% \\
\text { reduction from } 2011 \\
\text { to } 2013\end{array}$ & as baseline \\
\hline $\begin{array}{l}\text { 2B: Increase government savings by } \\
50 \% \text { and use remainder for direct } \\
\text { transfers to the poorest one third of } \\
\text { households }\end{array}$ & $\begin{array}{l}\text { increase transfers from } 30 \%- \\
100 \% \text { in } 2011 \text { to } 15 \%-50 \% \text { in } \\
2013\end{array}$ & $\begin{array}{l}33 \%, 50 \%, 100 \% \\
\text { reduction from } 2011 \\
\text { to } 2013\end{array}$ & as baseline \\
\hline $\begin{array}{l}2 \mathrm{C} \text { : Increase government savings by } \\
50 \% \text {, compensate only the poorest of } \\
\text { the poor, and use remainder for } \\
\text { productivity-enhancing investments }\end{array}$ & $\begin{array}{l}\text { increase transfers from } \\
20 \%-74 \% \text { in } 2011 \text { to } 20 \% \text { in } \\
2013\end{array}$ & $\begin{array}{l}33 \%, 50 \%, 100 \% \\
\text { reduction from } 2011 \\
\text { to } 2013\end{array}$ & $\begin{array}{l}7 \% \text { in construction, electricity, } \\
\text { water, trade and transport } \\
2011-2013 \text {; from } 2014,1 \% \\
\text { TFP growth in all sectors }\end{array}$ \\
\hline
\end{tabular}




\section{Impact of Fuel Subsidy Reform Options on Growth and Poverty}

\subsection{Accelerated versus Gradual Reform}

The first set of simulations ( $1 \mathrm{~A}$ and $2 \mathrm{~A}$ ) looks at a situation where the government reduces fuel subsidies and uses the full saving amount for budget deficit reduction. These scenarios can be broadly interpreted as pure fiscal consolidation scenarios [41]. Lower fuel subsidies have effects at the macro and household levels. At the macro level, they lead to an increase in inflation (and an appreciation of the real exchange rate) and a reduction in private consumption, exports and imports (Table 6). Investment increases because the redistribution of income from the private sector to the government raises the government's savings, thus increasing the economy's overall capital stock [42].

Table 6. Overview of macroeconomic effects.

\begin{tabular}{lcccccccc}
\hline \multirow{2}{*}{ Macro accounts } & \multirow{2}{*}{$\begin{array}{c}\text { Shares } \\
(\mathbf{\%})\end{array}$} & Baseline & \multicolumn{2}{c}{ Reform Option 1 (accelerated) } & \multicolumn{4}{c}{ Reform Option 2 (gradual) } \\
\cline { 5 - 9 } & & & $\mathbf{A}$ & $\mathbf{B}$ & $\mathbf{C}$ & $\mathbf{A}$ & $\mathbf{B}$ & $\mathbf{C}$ \\
\hline Consumption & 84.0 & 100.0 & 97.1 & 97.3 & 120.9 & 97.3 & 97.7 & 113.6 \\
$\quad$ Private & 66.4 & 100.0 & 96.2 & 96.6 & 127.2 & 96.5 & 97.0 & 117.6 \\
$\quad$ Public & 17.6 & 100.0 & 100.0 & 100.0 & 100.0 & 100.0 & 100.0 & 100.0 \\
Investment & 28.6 & 100.0 & 131.7 & 130.2 & 201.4 & 129.2 & 127.2 & 175.0 \\
Exports & 29.5 & 100.0 & 74.9 & 74.7 & 105.9 & 75.7 & 75.5 & 96.3 \\
Imports & 42.1 & 100.0 & 75.5 & 75.3 & 106.9 & 76.2 & 76.0 & 97.1 \\
Real exchange rate & 100.0 & 100.0 & 7.3 & 1.9 & 2.1 & 7.6 & 2.4 & 2.6 \\
\hline
\end{tabular}

Source: DCGE model results; Note: Results indexed to baseline (baseline $=100$ ). Real exchange as percent change from the base.

At the sector level, higher prices for fuel products increase intermediate input cost and reduce sectoral profitability and production, particularly in energy-intensive sectors. While the cost-push effects are felt immediately, the capacity effect sets in with a one-period time lag. Given that most of Yemen's oil is exported and re-imported as refined products, the reduction in fuel subsidies does not affect oil exports much but decrease fuel imports due to lower domestic demand. As a result, in the initial year of the reform, the GDP growth rate under the accelerated reform scenario (1A) falls short of the GDP growth rate under the baseline scenario and under the gradual reform scenario (2A), it only slightly exceeds the baseline growth rate (Figure 1). The immediate poverty effects of the reform are also much more pronounced under Scenario 1A than Scenario 2A. The poverty rate exceeds the baseline poverty rate by three percentage points in the initial reform year under Scenario 1A, while, under Scenario 2A, it is elevated by only 0.5 percentage points compared with the baseline rate. 
Figure 1. GDP growth and poverty reduction effects of accelerated (1A) versus gradual reform (1B).

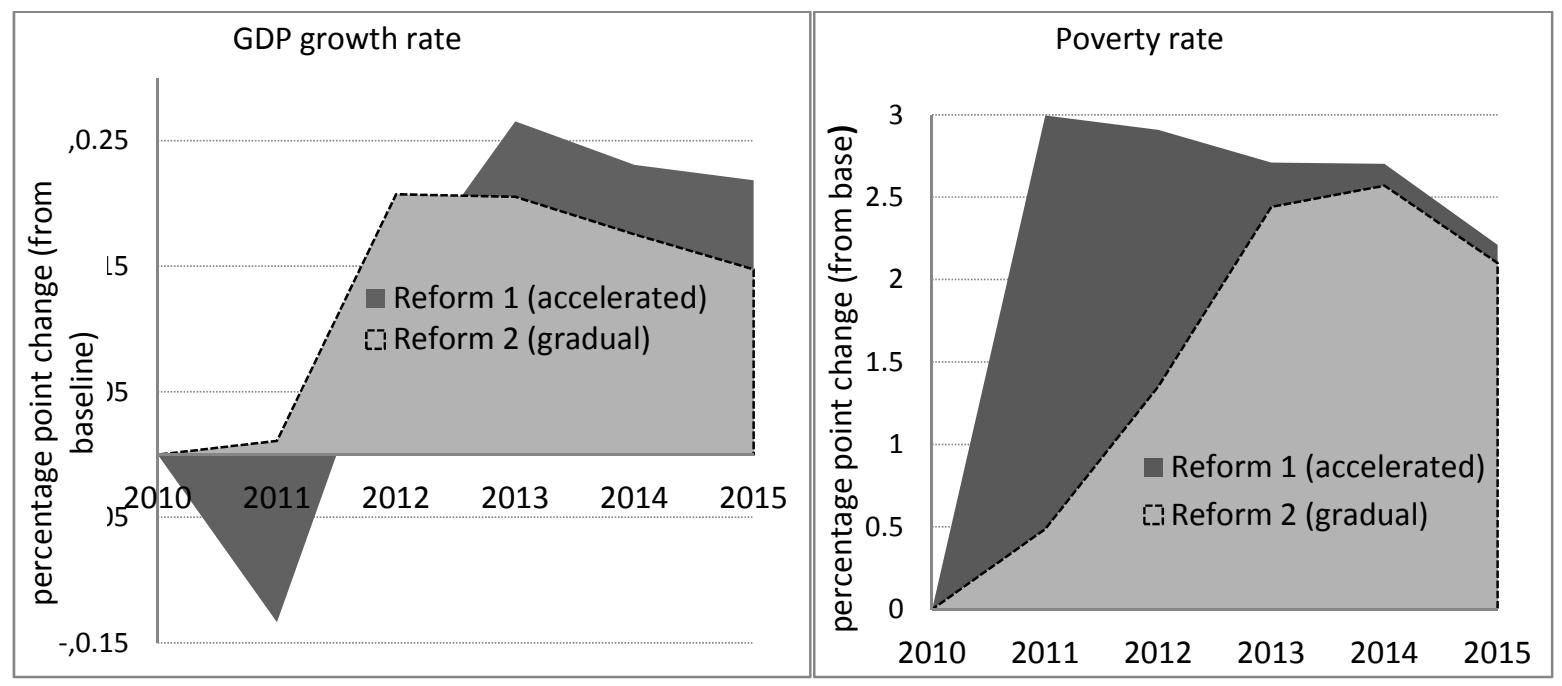

Source: DCGE model results; Note: GDP is reported at market prices, including indirect taxes.

\subsection{Timing and Design of the Reform Matter}

Rapid phasing-out of fuel subsidies leads to an initial drop in growth and a sharper spike in poverty, while gradual reductions smooth the growth and poverty effects. Slow phasing-out is therefore preferable from a growth and poverty-reduction perspective. Growth shocks, especially in the agricultural sector, are less pronounced, and total household income losses are about 20 percent lower. However, slow reform comes at higher fiscal costs, because subsidies effectively need to be financed for two more years compared with phasing out the subsidies within one year. The additional costs add up to 391 billion YER (Table 4). Thus, the faster the phasing-out of subsidies, the more fiscal space arises to compensate households and invest.

While the direction of growth and poverty effects are the same under the accelerated and gradual reform paths, the magnitudes of the effects differ across sectors depending on their production structure. The agricultural sector would be the hardest hit under both the accelerated and the gradual reform, mainly due to its strong dependence on diesel for irrigation (Table 7). Even with subsidies, fuel is the most expensive item in crop production, as nearly one-third of crop production intermediate expenditure is used for fuel purchase. The output especially of water-intensive crops like qat, fruits and vegetables drops, which lowers household incomes from agricultural production and export. Given its high profitability, qat production is less affected despite its intensive use of diesel for groundwater extraction. Compared with the baseline, agricultural growth declines by 4.1 percentage points in 2011 in the accelerated scenario and slows between 1.1 and 1.4 percentage points in 2011-13 annually in the gradual reform scenario. However, in both cases, agricultural growth resumes because it is no longer exposed to shocks that reduce profitability relative to the preceding year. The withdrawal of fuel subsidies also hits the industrial sector during the early years of reform. However, unlike in agriculture, growth is estimated to quickly recover and accelerate, initially because of the adjustment process and subsequently because of productivity gains 
and related new investment opportunities arising after reform, which improve competitiveness. Mainly due to the low substitutability and the domestic orientation of most services, the service sector is the least affected sector and continues to grow modestly during reform.

Table 7. Sector growth and poverty effects of fuel subsidy reform options.

\begin{tabular}{|c|c|c|c|c|c|c|c|}
\hline & 2009 & 2010 & 2011 & 2012 & 2013 & 2014 & 2015 \\
\hline Baseline & & \multicolumn{6}{|c|}{ Annual change } \\
\hline GDP (billion YER) & 5.1 & 4.52 & 4.30 & 4.27 & 4.24 & 4.20 & 4.18 \\
\hline $\begin{array}{l}\text { Poverty rate (percent of total } \\
\text { population) }\end{array}$ & 42.8 & -3.07 & -3.26 & -3.22 & -3.39 & -3.31 & -3.22 \\
\hline Reform Option 1 (accelerated) & Base & \multicolumn{6}{|c|}{ Annual change from base } \\
\hline \multicolumn{8}{|l|}{ Alternative $1 A$} \\
\hline GDP (share) & 100.0 & 0 & -0.13 & 0.13 & 0.27 & 0.23 & 0.22 \\
\hline Agriculture & 8.3 & 0 & -4.05 & 0.21 & 0.19 & 0.14 & 0.09 \\
\hline Industry & 38.3 & 0 & -1.15 & -0.22 & 0.21 & 0.17 & 0.17 \\
\hline Services & 53.4 & 0 & 0.79 & 0.29 & 0.40 & 0.35 & 0.33 \\
\hline Poverty rate (percent) & 42.8 & 0 & 3.00 & 2.91 & 2.71 & 2.70 & 2.21 \\
\hline Rural & 47.6 & 0 & 2.91 & 2.75 & 2.53 & 2.61 & 1.99 \\
\hline Nonfarm & 50.4 & 0 & 2.08 & 2.32 & 2.06 & 2.28 & 1.41 \\
\hline Farm & 42.0 & 0 & 4.58 & 3.62 & 3.48 & 3.29 & 3.18 \\
\hline Urban & 29.9 & 0 & 3.23 & 3.34 & 3.19 & 2.94 & 2.79 \\
\hline \multicolumn{8}{|l|}{ Alternative $1 B$} \\
\hline GDP (share) & 100.0 & 0 & -0.12 & 0.11 & 0.24 & 0.21 & 0.20 \\
\hline Agriculture & 8.3 & 0 & -3.56 & 0.18 & 0.17 & 0.11 & 0.07 \\
\hline Industry & 38.3 & 0 & -1.20 & -0.26 & 0.17 & 0.15 & 0.14 \\
\hline Services & 53.4 & 0 & 0.75 & 0.26 & 0.37 & 0.32 & 0.31 \\
\hline Poverty rate (percent) & 42.8 & 0 & 1.82 & 1.66 & 1.72 & 1.25 & 1.15 \\
\hline Rural & 47.6 & 0 & 1.29 & 0.98 & 1.17 & 0.60 & 0.54 \\
\hline Nonfarm & 50.4 & 0 & 0.34 & 0.43 & 0.68 & 0.15 & 0.01 \\
\hline Farm & 42.0 & 0 & 3.23 & 2.10 & 2.15 & 1.51 & 1.62 \\
\hline Urban & 29.9 & 0 & 3.22 & 3.44 & 3.18 & 2.96 & 2.75 \\
\hline \multicolumn{8}{|l|}{ Alternative $1 C$} \\
\hline GDP (share) & 100.0 & 0 & -0.04 & 1.15 & 0.89 & 0.91 & 0.88 \\
\hline Agriculture & 8.3 & 0 & 0.26 & 0.15 & -0.16 & -0.17 & -0.19 \\
\hline Industry & 38.3 & 0 & 2.18 & 1.88 & 1.44 & 1.46 & 1.39 \\
\hline Services & 53.4 & 0 & -0.78 & 1.46 & 1.11 & 1.09 & 1.01 \\
\hline Poverty rate (percent) & 42.8 & 0 & -0.03 & -1.34 & -3.10 & -4.72 & -6.03 \\
\hline Rural & 47.6 & 0 & -0.02 & -1.65 & -3.53 & -5.27 & -6.76 \\
\hline Nonfarm & 50.4 & 0 & -0.24 & -2.07 & -3.94 & -5.60 & -7.47 \\
\hline Farm & 42.0 & 0 & 0.44 & -0.79 & -2.68 & -4.58 & -5.30 \\
\hline Urban & 29.9 & 0 & -0.06 & -0.53 & -1.98 & -3.26 & -4.10 \\
\hline \multicolumn{8}{|c|}{ Compensation required for poorest one-third of households } \\
\hline Per household (YER) & 0 & 0 & 18,997 & 20,405 & 20,200 & 19,764 & 18,886 \\
\hline Total (billion YER) & 0 & 1 & 17 & 18 & 18 & 18 & 17 \\
\hline
\end{tabular}


Table 7. Cont.

\begin{tabular}{|c|c|c|c|c|c|c|c|}
\hline & 2009 & 2010 & 2011 & 2012 & 2013 & 2014 & 2015 \\
\hline Reform Option 2 (gradual) & Base & \multicolumn{6}{|c|}{ Annual change from base } \\
\hline \multicolumn{8}{|l|}{ Alternative $2 A$} \\
\hline GDP (share) & 100.0 & 0 & 0.01 & 0.21 & 0.21 & 0.18 & 0.15 \\
\hline Agriculture & 8.3 & 0 & -1.07 & -1.18 & -1.35 & 0.16 & 0.12 \\
\hline Industry & 38.3 & 0 & -0.28 & -0.37 & -0.46 & 0.02 & 0.18 \\
\hline Services & 53.4 & 0 & 0.23 & 0.31 & 0.42 & 0.31 & 0.35 \\
\hline Poverty rate (percent) & 42.8 & 0 & 0.49 & 1.35 & 2.44 & 2.57 & 2.10 \\
\hline Rural & 47.6 & 0 & 0.40 & 1.26 & 2.24 & 2.49 & 1.88 \\
\hline Nonfarm & 50.4 & 0 & 0.28 & 0.94 & 1.84 & 2.18 & 1.39 \\
\hline Farm & 42.0 & 0 & 0.63 & 1.91 & 3.05 & 3.13 & 2.89 \\
\hline Urban & 29.9 & 0 & 0.73 & 1.60 & 2.98 & 2.78 & 2.68 \\
\hline \multicolumn{8}{|l|}{ Alternative $2 B$} \\
\hline GDP (share) & 100.0 & 0 & 0.00 & 0.00 & 0.00 & 0.20 & 0.20 \\
\hline Agriculture & 8.3 & 0 & -0.90 & -1.00 & -1.10 & 0.10 & 0.10 \\
\hline Industry & 38.3 & 0 & -0.30 & -0.40 & -0.50 & 0.00 & 0.10 \\
\hline Services & 53.4 & 0 & 0.20 & 0.30 & 0.40 & 0.30 & 0.30 \\
\hline Poverty rate (percent) & 42.8 & 0 & 0.22 & 0.26 & 0.98 & 0.76 & 0.74 \\
\hline Rural & 47.6 & 0 & 0.09 & -0.18 & 0.29 & 0.00 & 0.06 \\
\hline Nonfarm & 50.4 & 0 & 0.00 & -0.54 & 0.27 & -0.08 & -0.16 \\
\hline Farm & 42.0 & 0 & 0.27 & 0.53 & 0.34 & 0.18 & 0.50 \\
\hline Urban & 29.9 & 0 & 0.58 & 1.42 & 2.79 & 2.74 & 2.55 \\
\hline \multicolumn{8}{|l|}{ Alternative $2 C$} \\
\hline GDP (share) & 100.0 & 0 & 0.00 & 0.30 & 0.40 & 0.70 & 0.70 \\
\hline Agriculture & 8.3 & 0 & 0.10 & 0.00 & -0.20 & -0.20 & -0.20 \\
\hline Industry & 38.3 & 0 & 0.60 & 0.90 & 0.90 & 1.10 & 1.20 \\
\hline Services & 53.4 & 0 & -0.20 & 0.20 & 0.50 & 0.90 & 0.90 \\
\hline Poverty rate (percent) & 42.8 & 0 & -0.33 & -0.96 & -1.49 & -2.82 & -4.28 \\
\hline Rural & 47.6 & 0 & -0.36 & -1.24 & -2.00 & -3.36 & -5.00 \\
\hline Nonfarm & 50.4 & 0 & -0.35 & -1.58 & -2.42 & -3.79 & -5.64 \\
\hline Farm & 42.0 & 0 & -0.37 & -0.55 & -1.15 & -2.49 & -3.70 \\
\hline Urban & 29.9 & 0 & -0.26 & -0.22 & -0.14 & -1.40 & -2.40 \\
\hline \multicolumn{8}{|c|}{ Compensation required for poorest one-third of households } \\
\hline Per household (YER) & 0 & 0 & 3,083 & 8,687 & 19,142 & 19,249 & 18,601 \\
\hline Total (billion YER) & 0 & 0 & 3 & 8 & 17 & 17 & 17 \\
\hline
\end{tabular}

Source: DCGE model results.

Reform without compensation [43] of households raises poverty rates up to three percentage points above baseline rates in the accelerated reform scenario and 2.6 percentage points in the gradual reform scenario. Under both scenarios, the poverty gap to the baseline rate starts declining after the reform is fully implemented (Figure 1), but it is important to note that it may take some more years for households to recover from real income losses, if no additional measures are taken. As an aggregate group, urban households are more affected than rural households, with poverty increases of between 3.0 and 3.3 percentage points compared with 2.5 and 3.0 percentage points for rural households (depending on the 
reform option chosen). However, as a subgroup of rural households, farm households are the most affected, especially those that rely on irrigation-intensive agriculture. Nonetheless, it is important to keep in mind that rural non-farm households that are less affected by the reform are higher in number and have higher initial poverty levels [44].

Given that poverty increases across all population groups and considering that many previous reforms without compensation of the poor failed inside and outside Yemen, the question arises as to how much would be needed to compensate at least the poorest of the poor. Simulation results show that compensating the poorest one-third of all households will require direct transfer payments of about 19,700 YER and 13,800 YER per household and year, under the accelerated and gradual reform scenario, respectively (Figure 2). The total annual cost of compensation for the bottom one-third during the period of 2010 to 2015 is estimated at about 17.6 billion YER under Scenario 1B and 12.3 billion YER under Scenario $2 \mathrm{~B}$ on average. Although the gap in poverty rates between the reform scenarios and the baseline scenario steadily shrinks over time after the completion of reform, household real incomes are likely to remain below their baseline levels for several more years as long as only parts of the savings of reform are used for compensating households, indicating that such direct transfers are not generating sufficient growth for sustainable fiscal and economic development.

Figure 2. Compensation required under the accelerated and gradual scenario.

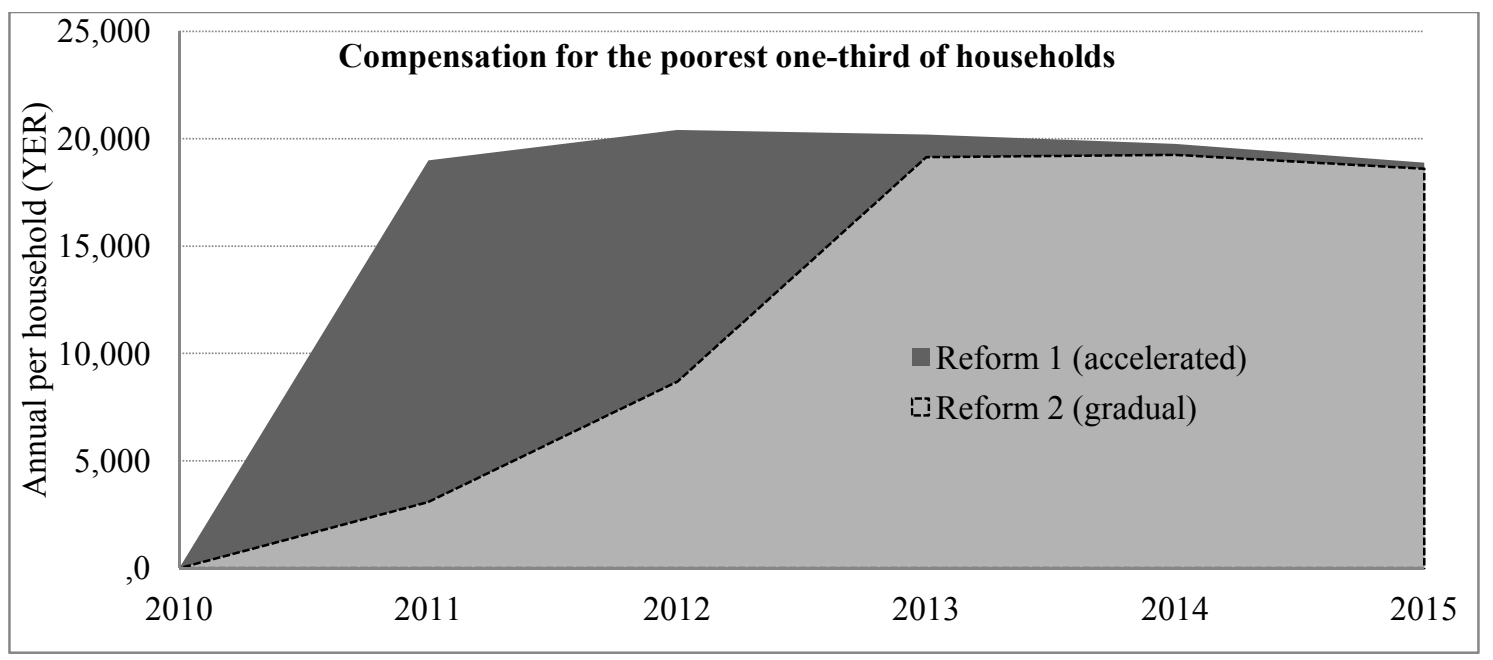

Source: DCGE model results.

\subsection{Using the Reform Savings for Fiscal Consolidation, Direct Transfers, and Investment}

Fuel subsidy reform would provide the Yemeni government with the financial resources to reduce the budget deficit, compensate affected households, and invest in generating additional growth, employment, and income opportunities. Yet the government's large budget deficit calls for a careful evaluation of spending alternatives and requires priority setting particularly with respect to the allocation of savings to direct transfer payments and investments. Comparison of the growth and poverty effects of Scenario 1B and $2 \mathrm{~B}$ and Scenario $1 \mathrm{C}$ and $2 \mathrm{C}$ reveals the trade-offs and synergies of spending the savings from the 
reform for cash transfers to households, which benefits them immediately, or productivity-enhancing investments, which tend to increase household incomes in the longer term. Given the urgent need for budget deficit reduction, half of the amount saved is allocated to fiscal consolidation in both scenario sets, and the other half is fully used for direct transfers to the poorest one third of households in Scenario $1 \mathrm{~B}$ and $2 \mathrm{~B}$, whereas it is split to compensate only the poorest one-third of all households and invest the rest into construction, electricity and water networks, and trade, transport and telecommunication infrastructure in Scenario 1C and 2C. The accumulated amount for investment equals 127 billion YER in Scenario 1C and 153 billion YER in Scenario 2C. After an initial time lag of two to three years, this public investment is expected to trigger additional growth in all sectors by creating higher economy-wide efficiencies.

Simulation results from Scenario 1B and 2B show that using all savings for direct transfers smoothes the negative income effects of reform on households substantially, but growth impulses for development are likely to be limited (Table 7). In addition, the impact of transfers strongly depends on the targeting and efficiency of delivery. The biggest beneficiaries under Scenario $1 \mathrm{~B}$ and $2 \mathrm{~B}$ are the group of rural households, since transfers are distributed according to households' initial poverty status and, across household groups, relative to their population sizes. Although direct transfers to the poorest cushion some of the negative short-term growth effects due to higher fuel prices, growth acceleration from those transfers still remains limited. The reasons are that the income multiplier effects are low, the import intensity of major consumer goods including food is high, and the positive effects on private consumption cannot compensate for the losses in other GDP components, especially exports. Thus, direct transfers will not be sufficient to alleviate the negative effects of fuel subsidy reform, and, furthermore, they may not be fiscally sustainable. Productivity-enhancing investments are hence needed in addition.

Infrastructural investments can make an important contribution to development and provide the foundation for sustained economic growth and household income generation through lowering transaction costs, integrating economic spaces across Yemen and restructuring agricultural, industrial and service value chains, which could be exploited by enabling domestic and foreign private investment. Simulation results from Scenario 1C and 2C reveal that, indeed, infrastructural investment-driven growth would have strong poverty-reducing effects also in the short term, in addition to its long-term development effects (Table 7). With these spending alternatives, poverty is predicted to decline across all household groups under the baseline poverty rates. The main driver of poverty reduction is the increased returns to factors, especially labor, resulting from growth acceleration. During the initial years of the investments, employment from related sectors, such as from jobs in construction, generates additional income for the poor. Then, when investment-induced direct effects phase out and other sectors start benefiting from new infrastructures, growth accelerates economy-wide and boosts the incomes of all households, including the poorest. Overall, poverty declines faster under the accelerated reform scenario (1C) than under the gradual reform scenario (2C). By the end of the six-year simulation period, the national poverty rate would have dropped by about six percentage points andfour4 percentage points below the baseline rate, respectively. The higher poverty-reducing effect of the accelerated reform scenario can be explained by the fact that more resources become earlier available for investment than under the gradual reform scenario, which 
then translate earlier into economy-wide growth effects. In both cases, rural and urban households benefit from a reform that uses savings for both direct transfers to the poorest households and productivity-enhancing investments (if investments are also spread to rural areas), unlike from a reform that does not involve investment (Scenario 1B and 2B).

The combination of direct transfers and investment is therefore a promising strategy for combining subsidy reform with the promotion of sustainable development. Transfer payments, investments, and resulting long-term productivity effects complement each other and lead to a significant reduction in poverty.

\section{Conclusion}

There is an urgent need for reforming Yemen's fuel subsidy scheme. Yemen is among the countries with the lowest fuel-pump prices in the world. Fuel subsidies make up 85 percent of all public spending related to economic affairs and exceed total spending on health, education and social protection combined. Investments in infrastructure and welfare spending-critical for economic growth and poverty reduction-remain at especially low levels. At the same time, Yemen faces a severe budget deficit and the costs of fuel subsidies are expected to further rise because of declining oil production and export, growing consumption and import of petroleum products. There is consensus that phasing out fuel subsidies has a large potential for the consolidation of the budget, but the direction and magnitude of the effects on growth and poverty are debated controversially. Lessons from other countries suggest that, while efficiency gains are likely to lead to significant growth acceleration after reform, poverty often increases during reform. Expected income losses motivate people's opposition to reform and may even spark civil unrest.

This paper contributes to the debate on the economic and social impact of fuel subsidy reform by analyzing the economic linkages between the existing fuel subsidy policy, government budget allocation and the role of the subsidies for production and consumption in Yemen. In addition, it provides a thorough analysis of the growth and poverty effects of alternative reform options. The results of the analysis may thus help Yemen's policy makers in designing a fuel subsidy reform that accelerates both economic development and poverty reduction and gains broad public approval.

Consistent with findings from other countries, our analysis shows that the direct effects of fuel subsidy reform on household real income in Yemen is likely to be modest given the low share of petroleum products in private expenditure. To also capture the indirect effects, which we found to be more crucial for household welfare, we use an economy-wide DCGE model combined with a microsimulation model. Simulation results reveal that reducing fuel subsidies would increase poverty among both rural and urban households, if all savings from subsidy reform are channeled to increased investment. Comparison of an accelerated reform scenario (that is removing all fuel subsidies within one year) versus a gradual reform scenario (that is, phasing-out fuel subsidies over a period of three years) suggest that the timing and design of reform matter: rapid phasing-out leads to an initial drop in growth and a sharper spike in poverty, while gradual reductions smoothen the growth and poverty effects. Gradual cutback of fuel subsidies over 
several years is therefore preferable from a growth and poverty-reduction perspective. However, slow reform comes at a higher fiscal expense, since maintaining parts of the subsidies ties up urgently needed financial resources. Hence, the faster the phasing-out of subsidies, the more fiscal space exists for the government to compensate households and to invest.

Compensating the poorest of the poor for their income losses during reform will be important for success, though it may not be sufficient. Simulation results show that direct transfer payments to the poorest one-third of all households adds up to 19,700 YER per household and year under our accelerated reform scenario and 13,800 YER under our gradual reform scenario on average. Generally, using half of all reform savings for direct transfers (and the other half for budget deficit reduction) strongly smoothes the negative effects on household incomes, but growth impulses for sustainable development are limited. Yet the impact of transfers essentially depends on the targeting and the efficiency of service delivery, too [45].

Phasing out the fuel subsidies and using the savings for a combination of fiscal consolidation, direct transfer payments to the poorest and productivity-enhancing investments in infrastructure is the most promising reform strategy. In the short term, direct transfers will mitigate the welfare impact from the reform among the poorest, and infrastructural investments will enhance income-earning opportunities especially in construction. Investments in water, electricity and transport, trade and construction sectors will also lower transaction costs and allow for the integration of economic spaces across Yemen. In the medium term, reforming fuel subsidies thus offers the creation of an impetus for restructuring of productive, agricultural, industrial and service value chains, which could be exploited by enabling domestic and foreign private investment. The short and medium-term effects from a need-oriented spending of the reform savings could not only avoid setbacks in poverty reduction but also facilitate propoor growth in Yemen.

The Government of Yemen has made first attempts to reform the fuel subsidies by reducing fuel prices in 2010. This paper has shown that continuing this reform process offers a great opportunity for development, if the transition to higher fuel prices is designed properly and the overall petroleum subsidy reform is integrated into Yemen's overall development strategy.

\section{Conflict of Interest}

The authors declare no conflict of interest.

\section{References and Notes}

1. World Bank. Yemen. Poverty Assessment Report; World Bank: Washington, DC, USA, 2007.

2. Breisinger, C.; Collion, M.H.; Diao, X.; Rondot, P. Impacts of the triple global crisis on growth and poverty in Yemen. Dev. Pol. Rev. 2011, 29, 155-184.

3. Ecker, O.; Breisinger, C.; McCool, C.; Diao, X.; Funes, J.; You, L.; Yu, B. Assessing Food Security in Yemen: An Innovative Integrated, Cross-Sector, and Multilevel Approach; Discussion Paper 982; International Food Policy Research Institute: Washington, DC, USA, 2010. 
4. WFP (World Food Programme). Yemen Comprehensive Food Security Survey 2010; VAM Food Security Analysis, WFP: Rome, Italy, 2010.

5. See Table A1 in the Appendix.

6. International Monetary Fund (IMF). Petroleum Subsidies in Yemen; International Monetary Fund: Washington, DC, USA, 2010.

7. See Figure A1 in the Appendix.

8. IEG World Bank. Climate Change and the World Bank Group: Phase I: An Evaluation of World Bank Win-Win Energy Policy Reforms; World Bank: Washington, DC, USA, 2008.

9. Coady, D.; El-Said, M.; Gillingham, R.; Kpodar, K.; Medas, P.; Newhouse, D. The Magnitude and Distribution of Fuel Subsidies: Evidence from Bolivia, Ghana, Jordan, Mali and Sri Lanka; Working Paper; International Monetary Fund: Washington, DC, USA, 2006.

10. Breisinger, C.; Ecker, O.; Al-Riffai, P.; Yu, B. Beyond the Arab Awakening: Policies and Investments for Poverty Reduction and Food Security; IFPRI Food Policy Report 25; International Food Policy Research Institute: Washington, DC, 2012.

11. Bacon, R.; Kojima, M. Phasing Out Subsidies: Recent Experiences with Fuel in Developing Countries; Public Policy for the Private Sector; World Bank: Washington, DC, USA, 2010.

12. In this paper we focus on economic and social impacts of subsidy reform. Environmental impacts, especially through reduction in greenhouse gas emissions, are expected to be positive (Ellis 2010).

13. Ellis, J. The Effects of Fossil-Fuel Subsidy Reform: A Review of Modelling and Empirical Studies. The Global Subsidies Initiative Series Untold Billions: Fossil Fuel Subsidies, Their Impacts and Path to Reform; International Institute for Sustainable Development: Geneva, Switzerland, 2010.

14. Jensen, J.; Tarr, D. Trade, Foreign Exchange, and Energy Policies in the Islamic Republic of Iran: Reform Agenda, Economic Implications, and Impact on the Poor; World Bank Policy Research Working Paper No. 2768; World Bank: Washington, DC, USA, 2002.

15. Burniaux, J.-M.; Chanteau, J.; Dellink, R.; Duval, R.; Jamet, S. The Economics of Climate Change Mitigation: How to Build the Necessary Global Action in a Cost-Effective Manner; OECD Economics Department Working Papers No. 701; OECD: Paris, France, 2009.

16. Von Moltke, A.; McKee, C.; Morgan, T. Energy Subsidies: Lessons Learned in Assessing Their Impact and Designing Policy Reforms; Greenleaf Publishing: Sheffield, UK, 2004.

17. Hope, E.; Singh, B. Energy Price Increases in Developing Countries; Policy Research Paper 1442; The World Bank: Washington, DC, USA, 1995.

18. Findings by Jensen and Tarr (2002), Burniaux (2009), and von Moltke, McKee, and Morgan (2004) are based on economic modeling. Hope and Singh (1995) base their results on simple correlation analysis, which makes isolating growth effects caused by the reform from other factors challenging. The authors also do not explain why growth in some countries have accelerated and in others not.

19. Ivanic, M.; Martin, W. Implications of higher global food prices for poverty in low-income countries. Agr. Econ. 2008, 39, 405-416.

20. Bacon, R.; Kojima, M. Phasing Out Subsidies: Recent Experiences with Fuel in Developing Countries; Public Policy for the Private Sector; World Bank: Washington, DC, USA, 2010. 
21. It is important to note that the overall annual fiscal costs for the fuel subsidies depend on the international prices for petroleum products, as the domestic price is fixed. In general, the higher the international price for petroleum products, the higher the costs for the subsidies.

22. Breisinger, C.; Ecker, O.; Funes, J.; Yu, B. Food as the Basis for Development. A Strategy for Yemen; IFPRI Discussion Paper 1036; International Food Policy Research Institute (IFPRI): Washington, DC, USA, 2010.

23. Ministry of Finance. Petroleum Subsidies in Yemen; Mimeo: Sanaa, Yemen, 2010.

24. See Table A2 in the Appendix.

25. In the analytical part of the paper, we will have to assume that subsidies are reduced across all fuel types.

26. Most irrigation schemes use diesel-operated pumps to extract ground water and irrigate fields.

27. HBS (Household Budget Survey). Central Statistical Organization. Raw data, unpublished work, 2005/2006.

28. SAM (Social Accounting Matrix). An Updated SAM for Yemen; Mimeo, International Food Policy Research Institute: Washington, DC, USA, 2009.

29. Diao, X.; Thurlow, J. A Recursive Dynamic Computable General Equilibrium Model. In Strategies and Priorities for African Agriculture. Economy-Wide Perspectives from Country Studies; Diao, X., Thurlow, J., Benin, S., Fan, S., Eds.; International Food Policy Research Institute: Washington, DC, USA, 2012.

30. Breisinger, C.; Diao, X.; Thurlow, J. Modeling growth options and structural change to reach middle income country status: The case of Ghana. Econ. Model. 2009, 26, 514-525.

31. Wiebelt, M.; Schweickert, R.; Breisinger, C.; Böhme, M. Oil Revenues for public investment in Africa: Targeting urban or rural areas? Rev. World Econ. 2011, 147, 745-770.

32. See Breisinger et al. 2011.

33. For a detailed list of production activities, commodities, factors of production, household types, and other accounts of the SAM, see Table A4 in the Appendix.

34. King, R.P.; Byerlee, D. Factor intensity and locational impacts of rural consumption patterns in Sierra Leone. Am. J. Agr. Econ. 1978, 60, 197-206.

35. Table A4 in the Appendix presents the complete list of imputed income elasticities.

36. These elasticities reflect the relative openness of trade in Yemen. The substitution elasticity is relatively high and assumes that Yemeni produces can relatively easily substitute intermediate (such as fuel) with production factors (such as labor).

37. See Table 5.

38. The DCGE model includes the current account of the government and therefore captures the annual flows of incomes and expenditures.

39. Dorosh, P.; Thurlow, J. Implications of Accelerated Agricultural Growth on Household Incomes and Poverty in Ethiopia: A General Equilibrium Analysis; ESSP-II Discussion Paper 2; International Food Policy Research Institute: Washington, DC, USA, 2009.

40. There is no similar previous study for MENA countries with similar topography. 
41. It is important to note that if the savings would be used for fiscal consolidation, positive longer-term effects can be expected such as higher credit ratings and lower interest rates. However, capturing these effects is beyond the scope of this paper.

42. It is important to note that phasing out fuel subsidies is a political challenge, a detailed discussion of which is beyond the scope of this paper. For example, a detailed stakeholder mapping for each fuel type may be required to understand the micro-level impacts of different fuels on each stakeholder group. Also, sequencing by fuel type may be considered in terms of what fuels may be phased out first. In general, gasoline tends to be the most regressive whereas the Government may want to remove kerosene subsidies last, especially as it is a much smaller component of the overall subsidy bill. Finally, a good communication strategy that explains why the reform is needed and how it is going to be implemented will likely be the key for successful reform.

43. It should also be noted that in addition to targeting the poorest, the Government may need to provide support to other stakeholder groups, especially those strong enough to block the reform process.

44. See Table A1 in the Appendix.

45. The Social Welfare Fund (SWF) and Social Fund for Development (SFD) have several social protection measures in place but are severely underfunded. They can serve as delivery channels of the considered transfer payments. In addition to expanding the SWF and SFD budgets, improving their service delivery and targeting may be needed for an effective compensation of the poorest. 


\section{Appendix}

Figure A1. Gasoline prices and GDP per capita in Middle East and North Africa countries, 2008.

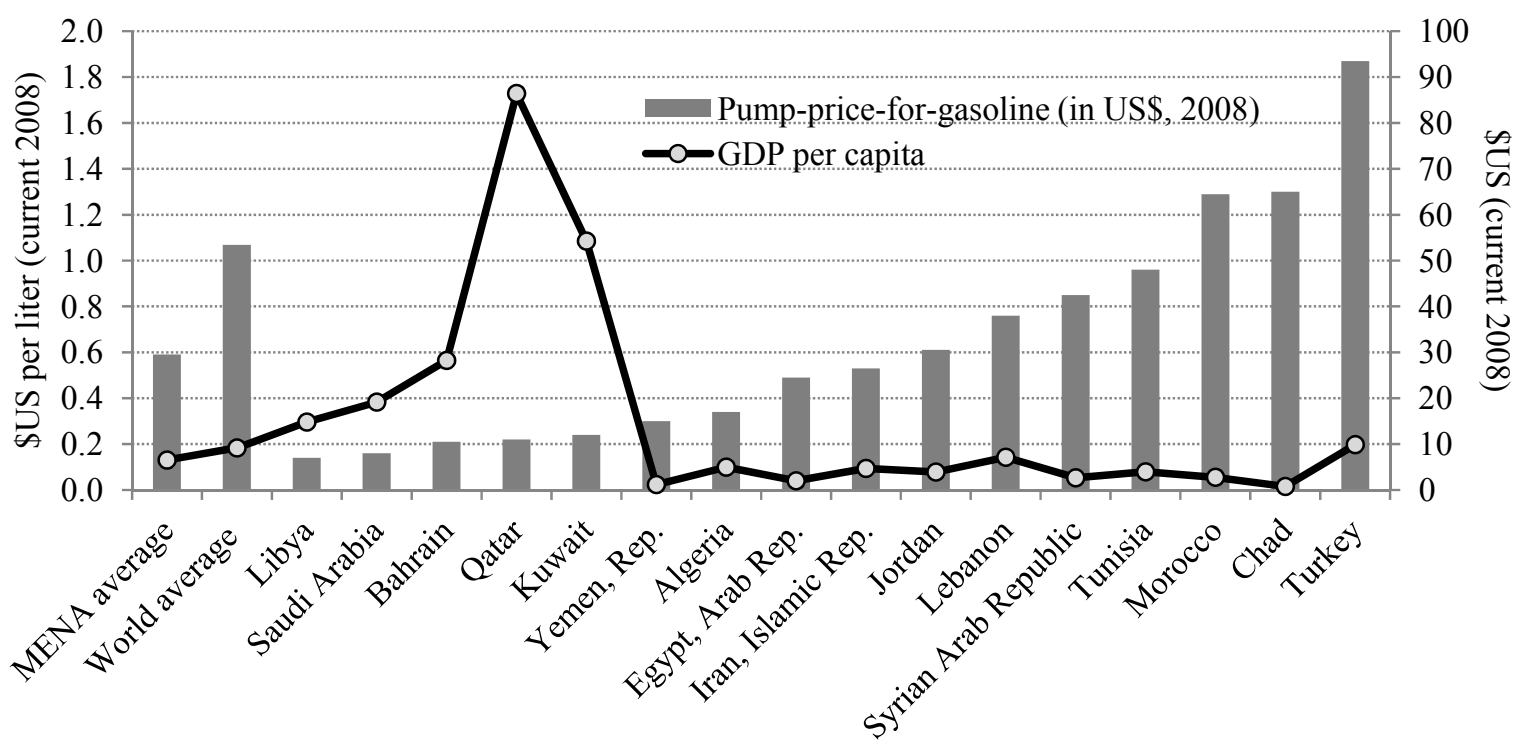

Source: Authors' representation based on GTZ [1].

Table A1. Summary of key household characteristics, 2009.

\begin{tabular}{ccccccc}
\hline & $\begin{array}{c}\text { Population } \\
\text { (thousand } \\
\text { people) }\end{array}$ & $\begin{array}{c}\text { Household } \\
\text { size (heads) }\end{array}$ & $\begin{array}{c}\text { Per capita } \\
\text { expenditure } \\
\text { (YER/year) }\end{array}$ & $\begin{array}{c}\text { Public transfer } \\
\text { (percent of } \\
\text { income) }\end{array}$ & $\begin{array}{c}\text { Poverty } \\
\text { (percent of total } \\
\text { population) }\end{array}$ & $\begin{array}{c}\text { Food insecurity } \\
\text { (pent of total }\end{array}$ \\
\hline Total & 23,307 & 7.8 & 145,593 & 4.0 & 42.8 & 32.1 \\
$\quad$ Rural & 17,086 & 8.0 & 122,201 & 3.3 & 47.6 & 37.3 \\
$\quad$ Farm & 5481 & 8.3 & 125,791 & 4.2 & 50.4 & 33.4 \\
$\quad$ Nonfarm & 11,605 & 7.9 & 114,600 & 2.9 & 42.0 & 39.2 \\
$\quad$ Urban & 6221 & 7.2 & 209,839 & 5.0 & 29.9 & 17.8 \\
Extreme poor & 7480 & 8.1 & 63,979 & 4.4 & & \\
\hline
\end{tabular}

Source: Based on HBS [2]; Note: Poverty and food security estimates are adopted from Breisinger et al. [3] and Ecker et al. [4]. 
Table A2. Subsidy expenditures by type of fuel.

\begin{tabular}{lccc}
\hline & $\mathbf{2 0 0 9}$ & $\mathbf{2 0 1 0 , \mathbf { Q 1 }}$ & $\mathbf{2 0 1 0} \mathbf{Q 2}$ \\
\hline Diesel & & & \\
Share in total subsidy (percent) & 69 & 63 & 65 \\
Domestic price (PEC \& large users) & 17 & 32 & 74 \\
Domestic subsidized price (small users) & 35 & 38 & 41 \\
Price at the Yemen border (incl. tax, freight, etc.) & 158 & 123 & 134 \\
Total annual diesel subsidy (billion YER) & 264 & 90 & 95 \\
\hline Gasoline & & & \\
Share in total subsidy & 14 & 22 & 23 \\
Domestic price & 60 & 63 & 68 \\
Price at the Yemen border (incl. tax, freight, etc.) & 87 & 121 & 130 \\
Total annual gasoline subsidy (billion YER) & 55 & 31 & 33 \\
Total subsidy reduction (savings) (YER/liter) & 0 & 3 & 5 \\
\hline LPG & & & \\
Share in total subsidy & 11 & 12 & 8 \\
Domestic price in YER/liter & 23 & 30 & 42 \\
Price at the Yemen border (incl. tax, freight, etc.) & 52 & 70 & 64 \\
Total annual LPG subsidy (billion YER) & 41 & 17 & 11 \\
Total subsidy reduction (savings) (YER/liter) & 0 & 7 & 11 \\
\hline Kerosene & & & \\
Share in total subsidy & 4 & 1 & 2 \\
Domestic price & 36 & 38 & 41 \\
Price at the Yemen border (incl. tax, freight, etc.) & 112 & 121 & 134 \\
Total annual kerosene subsidy (billion YER) & 15 & 1 & 3 \\
Total subsidy reduction (savings) (YER/liter) & 0 & 2 & 3 \\
\hline
\end{tabular}


Table A2. Cont.

\begin{tabular}{lccc}
\hline & 2009 & $2010, \mathrm{Q} 1$ & $2010, \mathrm{Q} 2$ \\
\hline Jet Fuel & 2 & 2 & 2 \\
Share in total subsidy & 36 & 39 & 43 \\
Domestic price & 97 & 123 & 136 \\
Price at the Yemen border (incl. tax, freight, etc.) & 9 & 3 & 4 \\
Subsidy (billion YER) & 63 & 69 & 68 \\
Subsidy as a percentage of import prices & 385 & 142 & 146 \\
Total fuel subsidy (billion YER) &
\end{tabular}

Sources: Yemen Ministry of Finance [5], IMF [6].

Table A3. Disaggregation of 2009 Yemen SAM.

\begin{tabular}{|c|c|c|}
\hline Activities/Commodities & & Factors of production \\
\hline Agriculture & Industry (cont.) & Labor \\
\hline Sorghum & Other processing & Private sector, unskilled \\
\hline Maize & Fish processing & Private sector, semiskilled \\
\hline Millet & Textiles and clothing & Private sector, skilled \\
\hline Wheat & Leather and shoes & Public sector, unskilled \\
\hline Barley & Wood & Public sector, semiskilled \\
\hline Other grains & Paper & Public sector, skilled \\
\hline Bananas & Printing & Capital \\
\hline Grapes & Oil refining & Capital \\
\hline Mangoes & Chemicals & Oil capital \\
\hline Citrus fruits & Fertilizer and pesticides & Gas capital \\
\hline Other fruits & Nonmetals & Land \\
\hline Potatoes & Metals & Households \\
\hline Onions & Machinery & Rural \\
\hline Tomatoes & Other manufacturing & Farm, food secure \\
\hline Other vegetables & Electricity & Farm, food insecure \\
\hline Pulses & Water & Nonfarm, food secure \\
\hline Coffee & Construction & Nonfarm, food insecure \\
\hline Sesame & Services & Urban \\
\hline Cotton & Trade & Urban, food secure \\
\hline Qat & Hotels and restaurants & Urban, food insecure \\
\hline Tobacco & Transport \& communication & Other accounts \\
\hline Camel & Business services & Enterprise \\
\hline Cattle & Health & Government \\
\hline Chicken & Education & Direct taxes \\
\hline Goats \& sheep & Public services & Sales taxes \\
\hline Fishery & Other services & Import tariffs \\
\hline Forestry & & Savings \& investment \\
\hline
\end{tabular}


Table A3. Cont.

\begin{tabular}{ll}
\hline Activities/Commodities & Factors of production \\
\hline Industry & Rest of world \\
Oil & \\
Gas & \\
Other mining & \\
Beverages & \\
Bread & \\
Other cereal-based food & \\
Dairy products \\
Vegetable oil \\
Sugar, processed \\
Camel meat \\
Beef \\
Poultry \\
Goat and sheep meat
\end{tabular}

Table A4. Elasticity of expenditure on food and services with respect to household incomes.

\begin{tabular}{lcc}
\hline Product & Rural & Urban \\
\hline Cereals & 0.31 & 0.28 \\
Bananas & 0.99 & 0.50 \\
Grapes & 0.89 & 0.79 \\
Mangoes & 0.80 & 0.75 \\
Other fruits & 1.58 & 1.39 \\
Potatoes & 0.40 & 0.40 \\
Vegetables & 0.62 & 0.57 \\
Coffee & 1.11 & 0.81 \\
Sesame & 0.62 & 0.57 \\
Qat & 1.25 & 0.93 \\
Tobacco & 1.11 & 0.81 \\
Meat & 1.02 & 0.49 \\
Wood & 0.38 & 0.28 \\
Fuel & 1.95 & 1.79 \\
Bread & 0.19 & 0.12 \\
Dairy products & 0.38 & 0.36 \\
Textiles & 1.31 & 1.14 \\
Other manufacturing & 2.89 & 1.22 \\
Chemicals & 0.83 & 0.74 \\
Water & 0.98 & 0.43 \\
Electricity & 1.03 & 0.65 \\
Private services & 2.18 & 1.55 \\
Public services & 3.22 & 1.22 \\
\hline
\end{tabular}

Source: Based on HBS [2]. 


\section{Appendix References and Notes}

1. GTZ (Gesellaschaft fuer Technische Zusammenarbeit). International fuel price database. Available online: http://www.gtz.de/en/themen/29957.htm (accessed in April 2010).

2. HBS (Household Budget Survey). 2005/2006. Central Statistical Organization. Raw data, unpublished work.

3. Breisinger, C.; Ecker, O.; Funes, J.; Yu, B. Food as the basis for development. A strategy for Yemen; IFPRI Discussion Paper 1036; International Food Policy Research Institute (IFPRI): Washington, DC, USA, 2010.

4. Ecker, O.; Breisinger, C.; McCool, C.; Diao, X.; Funes, J.; You, L.; Yu, B. Assessing Food Security in Yemen: An Innovative Integrated, Cross-Sector, and Multilevel Approach; Discussion Paper 982; International Food Policy Research Institute: Washington, DC, USA, 2010.

5. Ministry of Finance. Petroleum Subsidies in Yemen; Mimeo: Sanaa, Yemen, 2010.

6. International Monetary Fund (IMF). Petroleum Subsidies in Yemen; International Monetary Fund: Washington, DC, USA, 2010.

(C) 2012 by the authors; licensee MDPI, Basel, Switzerland. This article is an open access article distributed under the terms and conditions of the Creative Commons Attribution license (http://creativecommons.org/licenses/by/3.0/). 